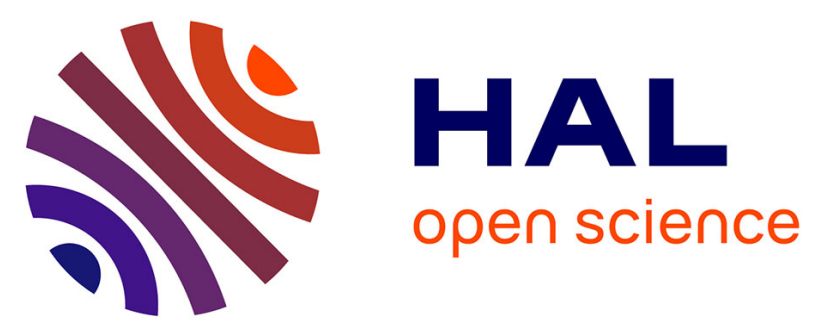

\title{
Involvement of multiple signaling pathways in PACAP-induced EM66 secretion from chromaffin cells
}

Johann Guillemot, Djida Ait-Ali, Valérie Turquier, Maite Montero-Hadjadje, Alain Fournier, Hubert Vaudry, Youssef Anouar, Laurent Yon

\section{- To cite this version:}

Johann Guillemot, Djida Aït-Ali, Valérie Turquier, Maite Montero-Hadjadje, Alain Fournier, et al.. Involvement of multiple signaling pathways in PACAP-induced EM66 secretion from chromaffin cells. Regulatory Peptides, 2006, 137 (1-2), pp.79 - 88. 10.1016/j.regpep.2006.04.023 . hal-01706412

HAL Id: hal-01706412

https://hal-normandie-univ.archives-ouvertes.fr/hal-01706412

Submitted on 18 Jul 2018

HAL is a multi-disciplinary open access archive for the deposit and dissemination of scientific research documents, whether they are published or not. The documents may come from teaching and research institutions in France or abroad, or from public or private research centers.
L'archive ouverte pluridisciplinaire HAL, est destinée au dépôt et à la diffusion de documents scientifiques de niveau recherche, publiés ou non, émanant des établissements d'enseignement et de recherche français ou étrangers, des laboratoires publics ou privés. 


\title{
Involvement of multiple signaling pathways in PACAP-induced EM66 secretion from chromaffin cells
}

\author{
Johann Guillemot ${ }^{\mathrm{a}}$, Djida Aït-Ali ${ }^{\mathrm{a}}$, Valérie Turquier ${ }^{\mathrm{a}}$, Maité Montero-Hadjadje ${ }^{\mathrm{a}}$, Alain Fournier ${ }^{\mathrm{b}}$, \\ Hubert Vaudry ${ }^{\mathrm{a}}$, Youssef Anouar ${ }^{\mathrm{a}}$, Laurent Yon ${ }^{\mathrm{a}, *}$ \\ a INSERM U413. European Institute for Peptide Research (IFRMP 23), Laboratory of Cellular and Molecular Neuroendocrinology,
University of Rouen, 76821 Mont-Saint-Aignan, France \\ ${ }^{\mathrm{b}}$ INRS-Institut Armand Frappier, University of Quebec, Pointe-Claire, PQ, Canada H9RIG6
}

\section{Introduction}

The secretory granules of adrenal medullary chromaffin cells contain a high concentration of soluble peptides and proteins, that are co-released with catecholamines into the circulation in response to splanchnic nerve stimulation. Among

Abbreviations: Cgs, chromogranins; CgA/B, chromogranin A/B; SgII, secretogranin II; SN, secretoneurin; PACAP, pituitary adenylate cyclaseactivating polypeptide; $\mathrm{PC}$, prohormone convertase.

* Corresponding author. Tel.: +33 23514 6945; fax: +33 235146946.

E-mail address: laurent.yon@univ-rouen.fr (L. Yon). the proteins stored in the chromaffin granules are the chromogranins (Cgs) which constitute a family encompassing chromogranin A ( $\mathrm{CgA})$, chromogranin $\mathrm{B}(\mathrm{CgB})$ and secretogranin II ( $\mathrm{SgII}$ ). Cgs are characterized by a high proportion of acidic amino acids and by the presence of multiple pairs of basic residues which represent potential cleavage sites for prohormone convertases (PC), suggesting that Cgs may serve as precursors to generate biologically active peptides. Indeed, several $\mathrm{CgA}$ - and $\mathrm{CgB}$-derived peptides, including vasostatin, chromostatin, pancreastatin, parastatin, chromacin, catestatin and secretolytin have been shown to exert biological activities [1]. Concerning SgII, a 33-amino acid peptide named secretoneurin $(\mathrm{SN})$ [2] has been shown to be implicated in 
angiogenesis, chemotaxis and modulation of the inflammatory response [3]. SgII is also the precursor of an evolutionarily conserved SN flanking-peptide termed EM66, in consideration of its $\mathrm{N}$ - and $\mathrm{C}$-terminal glutamic acid and methionine residues [4]. It was shown that EM66 is generated early during the ontogenesis of the fetal human adrenal gland [5] and that the peptide occurs in the secretory granules of adrenergic cells in the rat adrenal gland, as well as in gonadotrophs and lactotrophs in the rat pituitary, suggesting that upon stimulation, EM66 may be released to act as an autocrine, paracrine or endocrine factor [6]. There is also evidence that EM66 is involved in energy homeostasis since food deprivation induces a significant increase in the number of EM66-containing neurons of the jerboa hypothalamus [7]. Finally, it has been recently shown that EM66 is expressed in tumoral chromaffin cells and represents a sensitive diagnostic and pronostic marker of pheochromocytoma $[8,9]$.

Pituitary adenylate cyclase-activating polypeptide (PACAP), that is released from splanchnic nerve fibers innervating the adrenal medulla, acts as a regulator of chromaffin cell activity [10]. Indeed, PACAP has been shown to regulate, in vivo and in vitro, catecholamine and neuropeptide biosynthesis and release from chromaffin cells [11-17]. The effect of PACAP on chromaffin cells is mediated through the PACAP-preferring receptor, PAC1-R, via activation of the adenylate cyclase/PKA cascade and calcium $\left(\mathrm{Ca}^{2+}\right)$ influx (for review, [18]). In bovine adrenomedullary cells, nicotinic, histaminergic or PACAP stimulation increase SgII mRNA levels but not $\mathrm{CgA}$ expression [19-21]. PACAP also stimulates SN release through activation of the PKA and PKC pathways, and $\mathrm{Ca}^{2+}$ influx via L-type calcium channels [20]. Thus, PACAP activates multiple signaling pathways to regulate the synthesis and secretion of various neuropeptides, including SN, in primary chromaffin cells.

Although the function of EM66 is still unknown, several lines of evidence suggest that this peptide plays a role in the endocrine and neuroendocrine system. Determining the mechanisms that regulate the release of EM66 may contribute to the understanding of this role. In the present study, we have characterized EM66 and determined its localization in the bovine adrenal gland. We have also examined the signaling pathways activated by PACAP to regulate the secretion of EM66 from cultured bovine adrenochromaffin cells.

\section{Materials and methods}

\subsection{Peptides}

A fusion protein containing the human EM66 peptide was produced in Escherichia coli as previously described [5]. Briefly, the cDNA sequence encoding the EM66 region in human SgII was amplified by PCR, inserted downstream of the maltose-binding protein (MBP) region of the plasmid pMAL-c2 (New England Biolabs, Beverly, MA) and expressed in bacteria. The cleavage of the affinity-purified fusion protein with factor Xa released EM66 with the native amino acid sequence. The 38amino acid form of PACAP was synthesized by solid-phase methodology as previously described [22].

\subsection{Immunohistochemical procedure}

Frozen bovine adrenal medulla and cortex were sliced into $10-\mu \mathrm{m}$ sections with a cryomicrotome (Leica CM 3050, Heidelberg, Germany). Sections were thaw-mounted on gelatincoated slides, dried in a desiccator overnight at $4{ }^{\circ} \mathrm{C}$, and dipped for $10 \mathrm{~min}$ in Stephanini's fixative [4\% paraformaldehyde and $0.2 \%$ picric acid in phosphate buffer $(\mathrm{PB})]$. Slides with cultured chromaffin cells were dipped for $30 \mathrm{~min}$ in $4 \%$ paraformaldehyde in PB. After several rinses in PB, fixed tissues and cultured cells were processed for indirect immunofluorescence. Tissue sections and cultured cells were incubated overnight at $4{ }^{\circ} \mathrm{C}$ with an EM66 antiserum directed against human EM66 (code no. 736-1806) [5] diluted 1:200 and the mouse monoclonal antibody directed against tyrosine hydroxylase (TH; Chemicon International, Temecula, CA) diluted 1:500 in PB containing $0.3 \%$ Triton $\mathrm{X}-100$ and $1 \%$ bovine serum albumin (BSA, Roche Diagnostics, Mannheim, Germany). Then, they were rinsed in PB and incubated for $90 \mathrm{~min}$ at room temperature with fluorescein isothyocyanate-conjugated goat anti-rabbit $\gamma$-globulins (Caltag Laboratories, San Francisco, CA) diluted 1:100 and Texas Red-conjugated sheep anti-mouse $\boldsymbol{\gamma}$-globulins (Amersham Biosciences, Buckinghamshire, UK) diluted 1:50. Finally, tissues and cultured cells were rinsed in $\mathrm{PB}$, mounted with buffer/ glycerol (1:1), coverslipped, and examined using a confocal laser scanning microscope (CLSM TCS-SP2-AOBS, Leica) equipped with a fluorescence DMRX-A2 microscope and an argon (excitation wavelengths $458 / 476 / 488 / 514 \mathrm{~nm}$ ) and two helium/neon (excitation wavelengths 543 and $633 \mathrm{~nm}$, respectively) ion lasers. To verify the specificity of the immunoreaction, the following controls were performed: 1) substitution of the antiserum with $\mathrm{PB} ; 2)$ incubation with nonimmune serum instead of the EM66 antiserum; 3) preincubation of the EM66 antiserum diluted (1:200) with purified recombinant EM66 $\left(10^{-6} \mathrm{M}\right)$.

\subsection{Tissue extraction}

For reversed-phase HPLC analysis, frozen tissue samples were boiled for $10 \mathrm{~min}$ in $0.5 \mathrm{M}$ acetic acid, homogenized in a glass Potter, sonicated and centrifuged $\left(3000 \times g, 4^{\circ} \mathrm{C}, 30 \mathrm{~min}\right)$. The supernatants were collected and kept at $4{ }^{\circ} \mathrm{C}$ until prepurification. The pellets were used for measurement of protein concentrations by the Bradford method. Adrenal medulla extracts were prepared from $87.5 \mathrm{mg}$ wet tissue corresponding to $1.56 \mathrm{mg}$ protein and adrenal cortex extracts were prepared from $100 \mathrm{mg}$ wet tissue corresponding to $1.58 \mathrm{mg}$ protein. For Western blot analysis, bovine adrenal medulla or cortex was homogenized in $50 \mathrm{mM}$ Tris- $\mathrm{HCl}(\mathrm{pH} \mathrm{7.4)}$, containing $1 \%$ Triton X-100, $10 \mathrm{mM}$ EDTA and $1 \mathrm{mM}$ phenylmethylsulfonyl fluoride. After centrifugation $\left(21,000 \times g, 4{ }^{\circ} \mathrm{C}, 15 \mathrm{~min}\right)$, proteins contained in the supernatant were quantified using the Bradford method and then precipitated with $10 \%$ trichloroacetic acid.

\subsection{Prepurification of tissue extracts}

Each sample of adrenal tissue extract was loaded onto a SepPak $\mathrm{C}_{18}$ cartridge (Waters Corp., St-Quentin en Yvelines, France) 
equilibrated with a solution of $0.1 \%$ trifluoroacetic acid (TFA) in water. Bound material was eluted from the cartridge with a solution of acetonitrile/water/TFA (59.9:40:0.1, vol/vol/vol), dried by vacuum centrifugation and kept at room temperature until chromatographic analysis.

\subsection{HPLC analysis}

Prepurified samples were reconstituted in $1 \mathrm{ml}$ of $0.1 \%$ TFA in water, centrifuged $\left(21,000 \times g, 4{ }^{\circ} \mathrm{C}, 10 \mathrm{~min}\right)$ and injected onto a $4.6 \times 250-\mathrm{mm}$ Vydac $218 \mathrm{TP} 54\left(\mathrm{C}_{18}\right)$ column equilibrated with a solution of acetonitrile/water/TFA (9.9:90:0.1, vol/vol/ vol) at a flow rate of $1 \mathrm{ml} / \mathrm{min}$. The concentration of acetonitrile in the eluting solvent was raised to $60 \%$ over 25 min using a linear gradient. HPLC standard consisted of $1 \mu \mathrm{g}$ purified recombinant EM66. Fractions of $0.5 \mathrm{ml}$ were collected, evaporated and kept dry until RIA.

\subsection{Radioimmunoassay}

Purified recombinant EM66 was iodinated by the chloramine-T method and separated from free iodine on Sep-Pak $\mathrm{C}_{18}$ cartridges using a gradient of acetonitrile $(0-100 \%)$ in $0.1 \%$ TFA, as previously described [5]. The RIA was performed in veronal buffer ( $\mathrm{pH}$ 7.4) supplemented with $0.4 \%$ BSA and $0.1 \%$ Triton X-100. The EM66 antiserum, used at a final dilution of 1:48,000, was incubated with $7000 \mathrm{cpm}$ of tracer/ tube in the presence of graded concentrations of standard (purified EM66), culture medium, tissue extracts or HPLC fractions. After a 2 -day incubation at $4{ }^{\circ} \mathrm{C}$, the antibody-bound fraction was immunoprecipitated by addition of $200 \mu \mathrm{l}$ goat anti-rabbit $\gamma$-globulins (1:30), $200 \mu \mathrm{l}$ normal rabbit serum (1:150) and $1 \mathrm{ml}$ of $5 \%$ polyethyleneglycol 8000 . After a 2hour incubation at room temperature, the mixture was centrifuged $\left(5000 \times g, 4{ }^{\circ} \mathrm{C}, 30 \mathrm{~min}\right)$ and the pellet containing the bound fraction was counted on a gamma-counter (LKB, Wallack, Rockville, MD). The standard curve was set up with concentrations of EM66 ranging from 5 to $10,000 \mathrm{pg} /$ tube. The inter- and intra-assay coefficients of variation were, respectively, 5.00-9.24\% and $0.74-1.98 \%$ [8].

\subsection{Western blot analysis}

Proteins were electrophorezed on polyacrylamide gels under denaturing conditions (SDS-PAGE, 10\% total acrylamide), electroblotted onto nitrocellulose membranes (Amersham Pharmacia Biotech) and revealed with the various antisera using a chemiluminescence detection kit (Amersham Pharmacia Biotech). EM66, PC1 and PC2 antibodies were used at a dilution of 1:4000 and 1:1000, respectively. PC1 and PC2 antisera, raised in rabbit $[23,24]$, were a generous gift of Dr. N. Seidah (Montréal, Canada).

\subsection{Cell culture and treatments}

Primary cultures of bovine adrenochromaffin cells were obtained after retrograde perfusion of bovine adrenal glands with $0.1 \%$ collagenase (Serlabo, Bonneuil-sur-Marne, France) and $30 \mathrm{U} / \mathrm{ml}$ DNase I (Sigma-Aldrich), followed by mechanical dissociation of the digested adrenal medulla. Isolated cells were
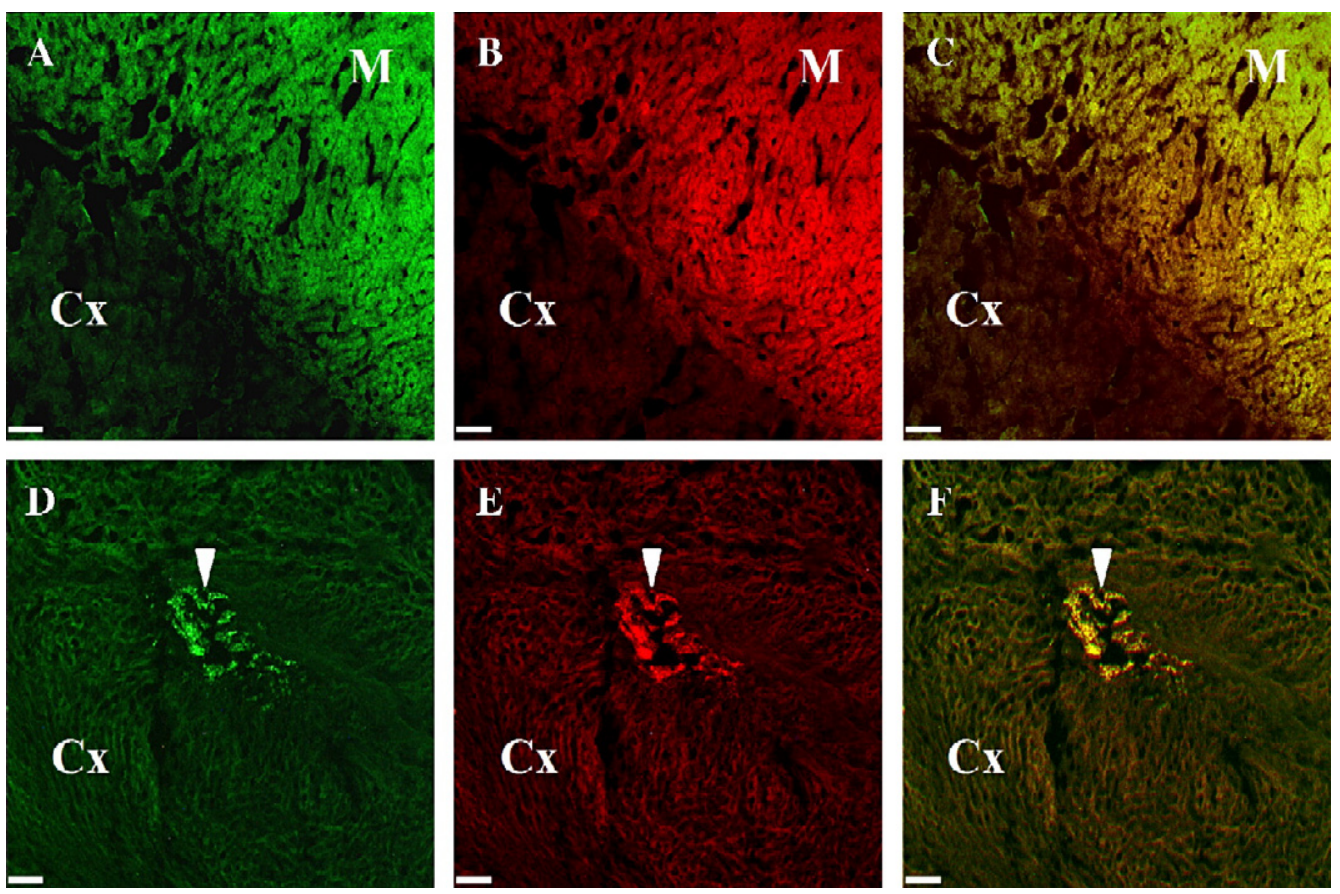

Fig. 1. Photomicrographs comparing the distribution of EM66 and TH immunoreactivity (IR) in the bovine adrenal gland and cultured bovine chromaffin cells. Intense immunofluorescence labeling of EM66 (A, D) and TH (B, E) is observed in the medulla (M) and in a cluster of chromaffin cells (arrowhead) located in the cortex (Cx). Note that cortical cells are devoid of staining. Combination of the images acquired in A and B, and in D and E, demonstrated the presence of EM66 in all chromaffin cells (C, F). Bars, $100 \mu \mathrm{m}$. 
cultured in DMEM (Sigma-Aldrich) supplemented with 5\% calf serum (Biowhittaker Europe, Verviers, Belgium), $100 \mathrm{U} / \mathrm{ml}$ penicillin, $100 \mu \mathrm{g} / \mathrm{ml}$ streptomycin and $0.25 \mu \mathrm{g} / \mathrm{ml}$ amphotericin B (Life Technologies, Cergy-Pontoise, France). Chromaffin cells were purified by differential plating to remove adherent nonchromaffin cells as described previously [25], and then plated at a density of $10^{6}$ cells $/ \mathrm{ml}$ in poly-L-lysine-coated $24-$ well plates (Sigma-Aldrich, Saint-Quentin Fallavier, France). After a resting period of one day, chromaffin cells were treated for $24 \mathrm{~h}$ with PACAP in the presence or absence of the nonspecific protein kinase inhibitor $\mathrm{H} 7(100 \mu \mathrm{M})$, the protein kinase A inhibitor H89 $(20 \mu \mathrm{M})$, the protein kinase $\mathrm{C}$ inhibitor chelerythrine $(5 \mu \mathrm{M})$, the nonselective $\mathrm{Ca}^{2+}$ channel blocker $\mathrm{NiCl}_{2}(3 \mathrm{mM})$, the cytosolic $\mathrm{Ca}^{2+}$ chelator BAPTA-AM $(50 \mu \mathrm{M})$, the L-type $\mathrm{Ca}^{2+}$ channel blocker nimodipine $(10 \mu \mathrm{M})$, the p42/44 ERK 1/2 MAPK inhibitor U0126 (10 $\mu \mathrm{M})$, the p38 MAPK inhibitor SB203580 $(10 \mu \mathrm{M})$, and the protein synthesis inhibitor cycloheximide $(0.5 \mu \mathrm{g} / \mathrm{ml})$. The drugs were either dissolved in the culture medium (cycloheximide), in dimethyl sulfoxide (H7, H89, chelerythrine, BAPTA-AM, nimodipine, SB203580 and U0126) or in ethanol (forskolin and TPA), and added $30 \mathrm{~min}$ before the onset of secretagogue treatment. The final concentration of dimethyl sulfoxide or ethanol never exceeded $0.1 \%$ except for BAPTA-AM $(0.2 \%)$,
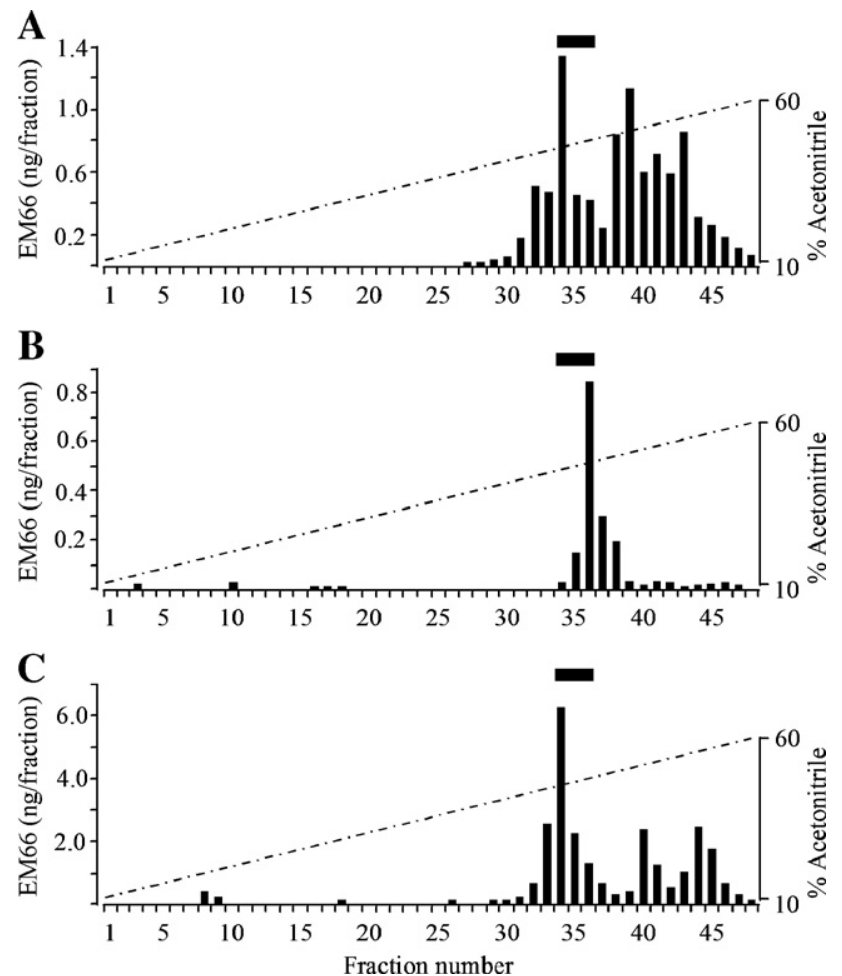

Fig. 2. Reversed-phase HPLC analysis of EM66-immunoreactivity in extracts of bovine adrenal medulla (A) and cortex (B), and in chromaffin cell culture medium (C). Samples were prepurified on Sep-Pak cartridges and chromatographed onto a Vydac $\mathrm{C}_{18}$ column. Fractions were collected $(0.5 \mathrm{ml} /$ tube $)$, dried and radioimmunoassayed for EM66. The bars above the peaks indicate the elution position of recombinant EM66 chromatographed the same day as the extracts. The dashed lines show the concentration of acetonitrile in the eluting solvent. and control cells were treated with the same amount of solvent. After the incubation period, aliquots of culture medium supernatants were taken and immediately frozen at $-20{ }^{\circ} \mathrm{C}$ until RIA determination of EM66. For immunocytochemical experiments, cells were cultured on glass slides coated with poly-L-lysine.

\subsection{Data analysis}

Data are reported as median (25th-75th percentile), where the 25th-75th percentile represents the dispersion of the distribution. The nonparametric Mann-Whitney $U$ test and Kruskal-Wallis test were used. Probability values less than 0.05 were considered significant. Data were analyzed with the Prism program (GraphPad Software, San Diego, CA).

\section{Results}

\subsection{Immunohistochemical detection of EM66}

In the adrenal gland, the EM66 antibody strongly labeled the medulla (Fig. 1A) and groups of cells located in the cortex (Fig. 1D). Double labeling experiments revealed that adrenomedullary and cortical cells that were immunolabeled with the EM66 antiserum were also stained with the TH antibodies (Fig. 1A and F), indicating that EM66-IR material is restricted to chromaffin cells. Preabsorption of the primary antiserum with $10^{-6} \mathrm{M}$ EM66 totally abolished the immunoreaction (data not shown). When the antiserum was substituted with either nonimmune rabbit serum or PB, no immunostaining was observed.

\subsection{Characterization of EM66-IR in bovine adrenal gland}

HPLC analysis combined with RIA detection was performed to characterize EM66 in adrenal gland extracts and chromaffin cell culture medium (Fig. 2). The position of the main immunoreactive peak of recombinant EM66 varied between fractions 34 and 36 (44-46\% acetonitrile), depending on the experiment (data not shown). In adrenal medulla and adrenal cortex extracts as in culture medium, a major immunoreactive peak was resolved that co-eluted with recombinant EM66 (Fig. 2A, B and $\mathrm{C}$, respectively). More hydrophobic EM66-immunoreactive compounds eluting in fractions 39-45 (49-55\% acetonitrile) were also resolved in the adrenal medulla extracts and culture medium (Fig. 2A and $\mathrm{C}$, respectively).

As previously described [26], in bovine adrenal medulla, Western blot analysis using the EM66 antiserum revealed the presence of a SgII-immunoreactive band with an apparent molecular mass of 97-kDa (Fig. 3, lane 1M). The same band with less intensity was observed in adrenal cortex extracts (Fig. 3, lane $1 \mathrm{Cx})$. Adrenal medulla and cortex extracts exhibited additional bands of lower mass but with a different pattern (Fig. 3, lane 1). Immunoblots with anti-PC1 and $\mathrm{PC} 2$ indicated that bovine adrenal medulla expresses both convertases as revealed by the $66-\mathrm{kDa}$ bands (Fig. 3, lanes $2 \mathrm{M}-3 \mathrm{M}$ ). In the adrenal cortex, a less intense PC1-immunoreactive band (Fig. 3, lane 


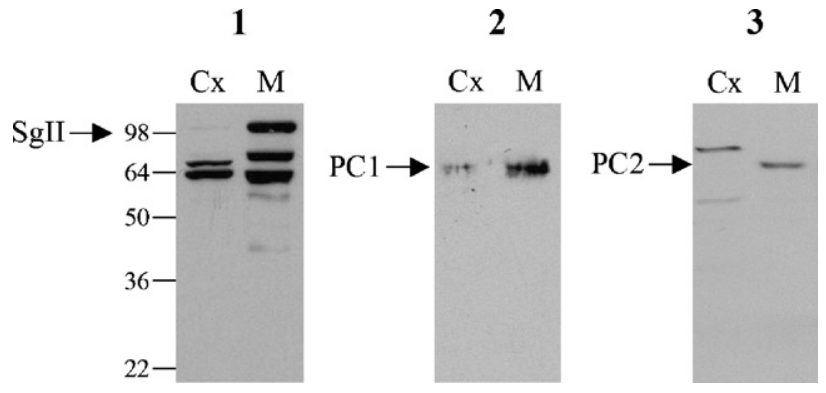

Fig. 3. Western blot analysis of SgII, PC1 and PC2 in bovine adrenal gland extracts. Adrenal cortex $(\mathrm{Cx})$ and adrenal medulla (M) samples were homogenized and proteins $(20 \mu \mathrm{g})$ were analyzed by SDS-PAGE followed by immunoblotting using the EM66 antiserum diluted 1:4000 (lane 1), a PC1 antiserum diluted 1:1000 (lane 2) or a PC2 antiserum diluted 1:1000 (lane 3). Molecular weight markers (in $\mathrm{kDa}$ ) and the SgII, $\mathrm{PC} 1$ and $\mathrm{PC} 2$ positions are indicated.

$2 \mathrm{Cx})$ and a band of $80-\mathrm{kDa}$ corresponding to a non-processed form of PC2 (Fig. 3, lane 3Cx) were observed.

\subsection{EM66 levels in the bovine adrenal gland}

Serial dilutions of adrenal medulla extracts generated displacement curves that were parallel to those obtained with recombinant EM66 (Fig. 4A). Similar results were obtained with adrenal cortex extracts (Fig. 4A). EM66 concentrations determined from adrenal medulla extracts $(n=5)$ ranged from 26.5 to $93.3 \mathrm{ng} / \mathrm{mg}$ protein with a median value of $35.9 \mathrm{ng} / \mathrm{mg}$ protein (Fig. 4B). In the cortex $(n=5)$, EM66 levels were about 45 -fold lower with values ranging from 0.6 to $1.8 \mathrm{ng} / \mathrm{mg}$ protein with a median of $0.8 \mathrm{ng} / \mathrm{mg}$ protein (Fig. 4B).

\subsection{PACAP stimulates EM66 release from cultured chromaffin cells}

After a 24-hour resting period in the absence of any secretagogue, bovine chromaffin cells released EM66 in the culture medium at a rate of $6.9(6.6-7.2) \mathrm{ng} / 10^{5}$ cells per $24 \mathrm{~h}$ (Fig. 5A). Incubation of cells with graded concentrations of PACAP $(0.1 \mathrm{nM}-1 \mu \mathrm{M})$ for $24 \mathrm{~h}$ induced a dose-dependent stimulation of EM66 release (up to 2.5-fold) with half-maximal $\left(\mathrm{ED}_{50}\right)$ effect at a concentration of $4.8 \mathrm{nM}$. Kinetic experiments showed that PACAP $(50 \mathrm{nM})$ evoked EM66 release in the medium after $6 \mathrm{~h}$ of treatment (Fig. 5B). The PACAP effect gradually increased to reach a 2.6-fold stimulation after $48 \mathrm{~h}$, remained elevated at $72 \mathrm{~h}$ and then declined at $96 \mathrm{~h}$ (Fig. 5B). Although the RIA measures mainly the EM66 peptide, other EM66-containing fragments are also included in this measurement as indicated by the HPLC analysis.

\subsection{Contribution of calcium signaling to PACAP-induced EM66 release}

The nonselective $\mathrm{Ca}^{2+}$ channel blocker $\mathrm{NiCl}_{2}(3 \mathrm{mM})$, the cytosolic $\mathrm{Ca}^{2+}$ chelator BAPTA-AM $(50 \mu \mathrm{M})$ and the L-type $\mathrm{Ca}^{2+}$ channel blocker nimodipine $(10 \mu \mathrm{M})$ significantly inhibited by $78 \%, 65 \%$ and $57 \%$, respectively, the stimulatory effect of PACAP on EM66 release. None of these drugs had any effect on EM66 secretion by its own (Fig. 6).

\subsection{Contribution of protein kinases to PACAP-induced EM66 release}

The nonselective protein kinase inhibitor H7 $(100 \mu \mathrm{M})$ markedly reduced $(-90 \%)$ the effect of PACAP on EM66 release. The effect of PACAP was also significantly diminished by the PKA inhibitor H89 $(20 \mu \mathrm{M})$ and the PKC inhibitor chelerythrine $(5 \mu \mathrm{M})(-77 \%$ and $-63 \%$, respectively) (Fig. 7). Concomitant administration of $\mathrm{H7}$ with BAPTA or with nimodipine reduced PACAP-induced EM66 release by $84 \%$ and $90 \%$, respectively (Fig. 8). The association of $\mathrm{H} 7$ with the extracellular and intracellular $\mathrm{Ca}^{2+}$ chelators $\mathrm{NiCl}_{2}$ and BAPTA totally abolished the stimulatory effect of PACAP on EM66 secretion. A similar blockage was observed when

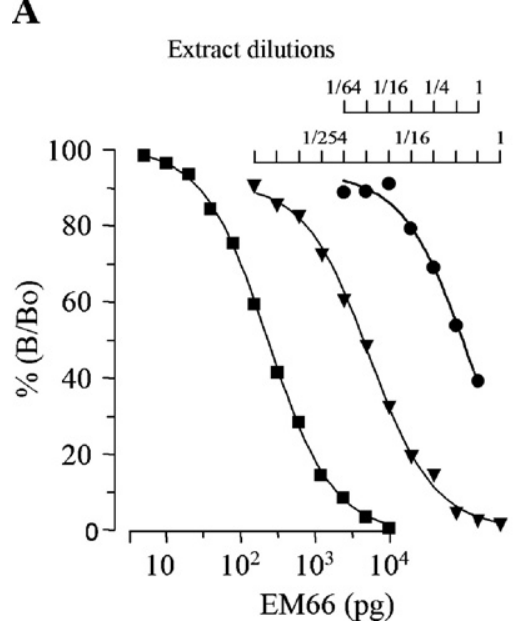

\section{B}

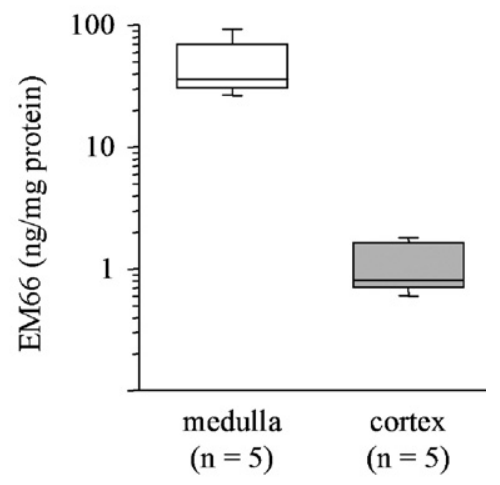

Fig. 4. (A) Semilogarithmic plots comparing competitive inhibition of antibody-bound ${ }^{125}$ I-EM66 by recombinant EM66 ( $\left.\mathbf{\square}\right)$ and serial dilutions of adrenal medulla

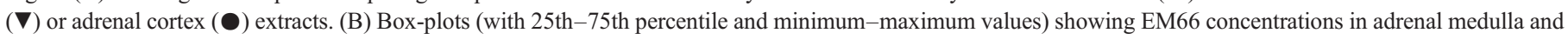
adrenal cortex extracts. 
A
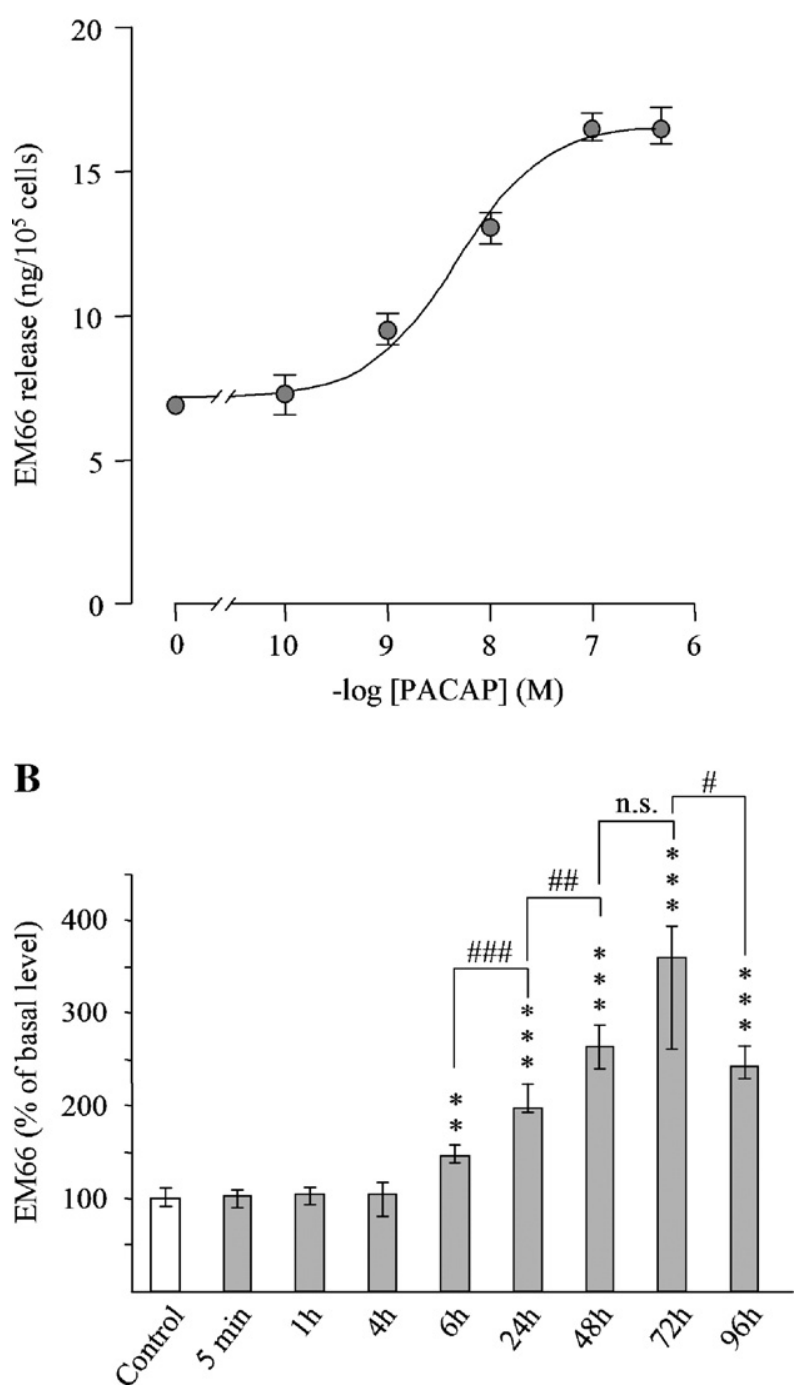

Fig. 5. (A) Dose-dependent effect of PACAP on EM66 release from cultured bovine chromaffin cells. Values are expressed as nanograms of EM66 secreted by $10^{5}$ cells and represent the median and 25 th-75th percentile. The $\mathrm{EC}_{50}$ value was $4.8 \mathrm{nM}$. (B) Time-course of PACAP-induced EM66 release. Chromaffin cells were incubated $24 \mathrm{~h}$ in the absence (control; open bar) or presence of $50 \mathrm{nM}$ PACAP for various durations. Values represent the median and 25th75th percentile of EM66 concentration in the culture medium, expressed as percentages of basal level. n.s., not significant; ${ }^{* *} p<0.01,{ }^{* * *} p<0.001$ vs the corresponding control; ${ }^{\#} p<0.05,{ }^{\# \#} p<0.01,{ }^{\# \#} p<0.001$.

PACAP was co-incubated with chelerythrine, $\mathrm{H} 89, \mathrm{NiCl}_{2}$ and BAPTA (Fig. 8).

\subsection{Contribution of MAP kinases to PACAP-induced EM66 release}

The $\mathrm{p} 38$ MAPK inhibitor SB203580 $(10 \mu \mathrm{M})$ and the $\mathrm{p} 42 / 44$ ERK1/2 MAPK inhibitor U0126 $(10 \mu \mathrm{M})$ decreased, respectively, by $72 \%$ and $63 \%$ the effect of PACAP on EM66 release (Fig. 9). Concomitant administration of both inhibitors suppressed by 93\% PACAP-induced EM66 secretion (Fig. 9). The two inhibitors, alone or in combination, had no effect on peptide release.

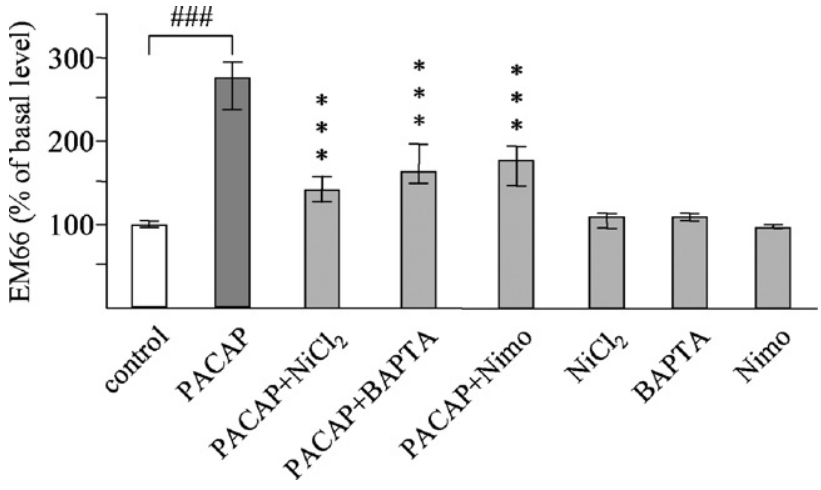

Fig. 6. Effect of $\mathrm{Ca}^{2+}$ mobilization inhibitors on PACAP-induced EM66 release. Chromaffin cells were incubated $24 \mathrm{~h}$ in control conditions or with $50 \mathrm{nM}$ PACAP, in the absence or presence of $3 \mathrm{mM} \mathrm{NiCl}_{2}, 50 \mu \mathrm{M}$ BAPTA or $10 \mu \mathrm{M}$ nimodipine (Nimo). Values represent the median and 25th-75th percentile of EM66 concentration in the culture medium, expressed as percentages of basal level (corresponding controls). ${ }^{\# \# \#} p<0.001$ PACAP $v s$ control, ${ }^{* * *} p<0.001 v s$ PACAP alone.

\subsection{Contribution of protein synthesis to PACAP-induced EM66 release}

The stimulatory effect of PACAP (50 nM) on EM66 release was mimicked by forskolin $(25 \mu \mathrm{M})$ and $\mathrm{K}^{+}(25 \mathrm{mM})$, and to a lesser extent by TPA $(100 \mathrm{nM})$ (Fig. 10). The protein synthesis inhibitor cycloheximide $(0.5 \mu \mathrm{g} / \mathrm{ml})$, reduced by $80-90 \%$ the action of PACAP as well as that of forskolin and $\mathrm{K}^{+}$on EM66 release. In contrast, the effect of TPA was not affected by cycloheximide (Fig. 10).

\section{Discussion}

The results described in the present study have shown that bovine adrenochromaffin cells are able to produce and release the SgII-derived peptide EM66, and that PACAP is a strong regulator of this process through activation of diverse signaling components.

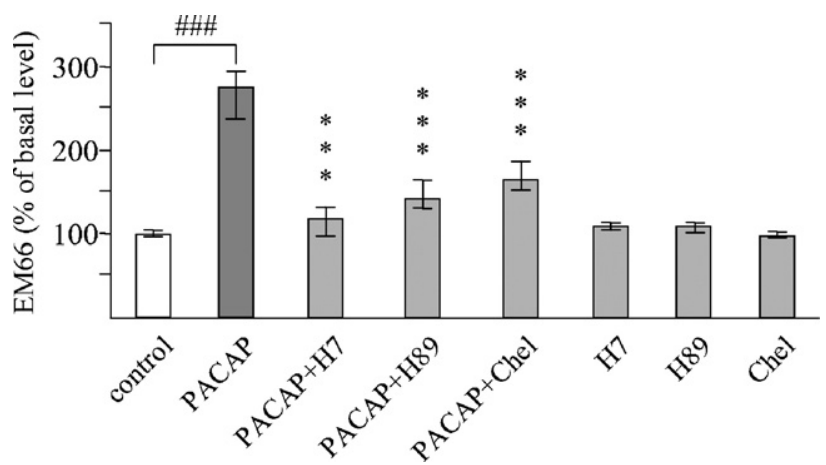

Fig. 7. Effect of protein kinase inhibitors on PACAP-induced EM66 release Chromaffin cells were incubated $24 \mathrm{~h}$ in control conditions or with $50 \mathrm{nM}$ PACAP, in the absence or presence of $100 \mu \mathrm{M} \mathrm{H} 7,20 \mu \mathrm{M} \mathrm{H} 89$ or $5 \mu \mathrm{M}$ chelerythrine (Chel). Values represent the median and 25th-75th percentile of EM66 concentration in the culture medium, expressed as percentages of basal level (corresponding controls). ${ }^{\# \# \#} p<0.001$ PACAP $v s$ control, ${ }^{* * *} p<0.001 v \mathrm{~s}$ PACAP alone. 


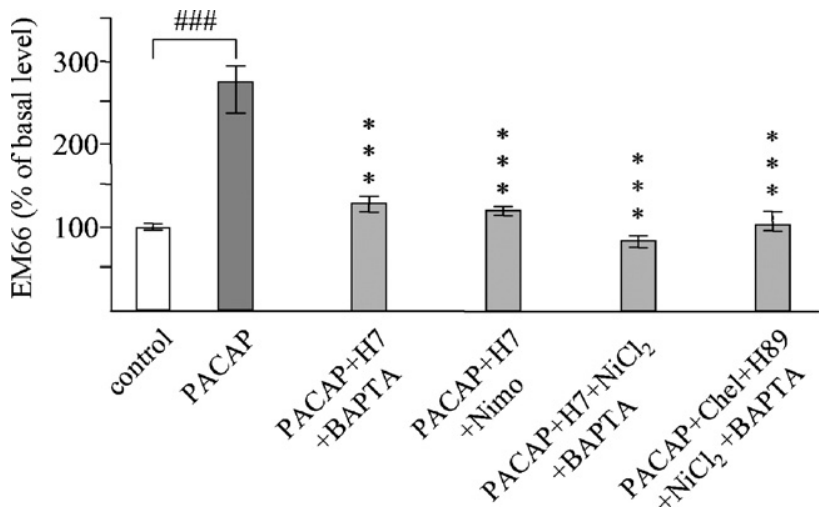

Fig. 8. Effect of concomitant administration of protein kinase inhibitors and $\mathrm{Ca}^{2+}$ mobilization inhibitors on PACAP-induced EM66 release. Chromaffin cells were incubated for $24 \mathrm{~h}$ in control conditions or with $50 \mathrm{nM}$ PACAP, in the absence or presence of $100 \mu \mathrm{M} \mathrm{H7}, 50 \mathrm{nM}$ BAPTA, $10 \mu \mathrm{M}$ nimodipine (Nimo), $3 \mathrm{mM}$ $\mathrm{NiCl}_{2}, 5 \mu \mathrm{M}$ chelerythrine (Chel) or $20 \mu \mathrm{M} \mathrm{H} 89$. Values represent the median and 25th-75th percentile of EM66 concentration in the culture medium, expressed as percentages of basal level (corresponding controls). ${ }^{\# \#} p<0.001$ PACAP vs control, ${ }^{* * *} p<0.001 v s$ PACAP alone.

Double labeling experiments revealed that EM66-IR is present in TH-producing cells i.e. chromaffin cells of the adrenal medulla, consistent with the data previously obtained in rat chromaffin cells [6]. As in the rat adrenal gland [6], islets of EM66-positive chromaffin cells were also observed within the adrenal cortex. Several studies have indicated the existence of rays and islets of extramedullary chromaffin cells in the adrenal gland [27-29]. The occurrence of EM66 in these cells suggests that the peptide could play a role as a paracrine factor to regulate steroidogenic cells in the adrenal gland [30,31].

HPLC analysis combined with RIA detection of adrenal medulla and adrenal cortex extracts, resolved a major immunoreactive peak that co-eluted with purified recombinant EM66, indicating that this peptide is produced in the adrenal gland. In fact, our previous observations indicated that $\mathrm{SgII}$ is actually processed to form EM66 in the human and rat adrenal gland $[5,6,9]$, in the rat pituitary $[6]$ and in the jerboa hypothalamus

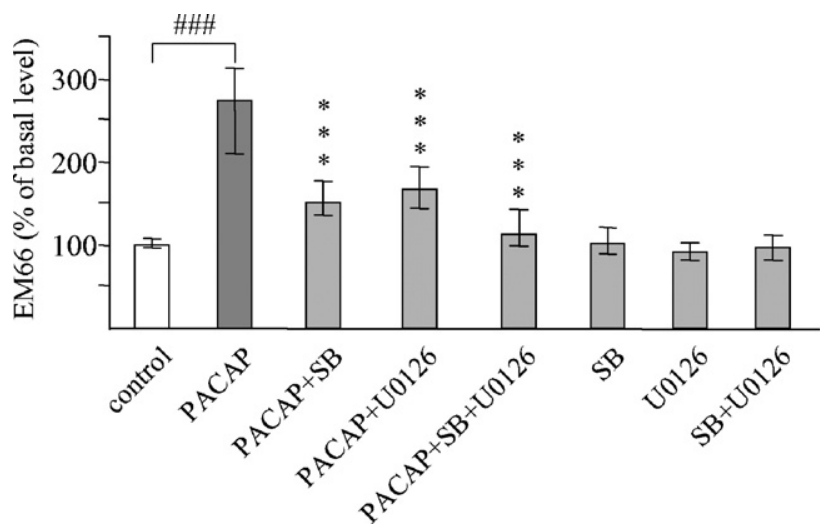

Fig. 9. Effect of MAPK inhibitors on PACAP-induced EM66 release. Chromaffin cells were incubated for $24 \mathrm{~h}$ in control conditions or with $50 \mathrm{nM}$ PACAP, in the absence or presence of $10 \mu \mathrm{M} \mathrm{SB} 203580$ (SB), $10 \mu \mathrm{M} \mathrm{U} 0126$ or a combination of both drugs. Values represent the median and 25 th -75 th percentile of EM66 concentration in the culture medium, expressed as percentages of basal level (corresponding controls). ${ }^{\# \#} p<0.001$ PACAP $v s$ control, $* * * p<0.001$ vs PACAP alone.

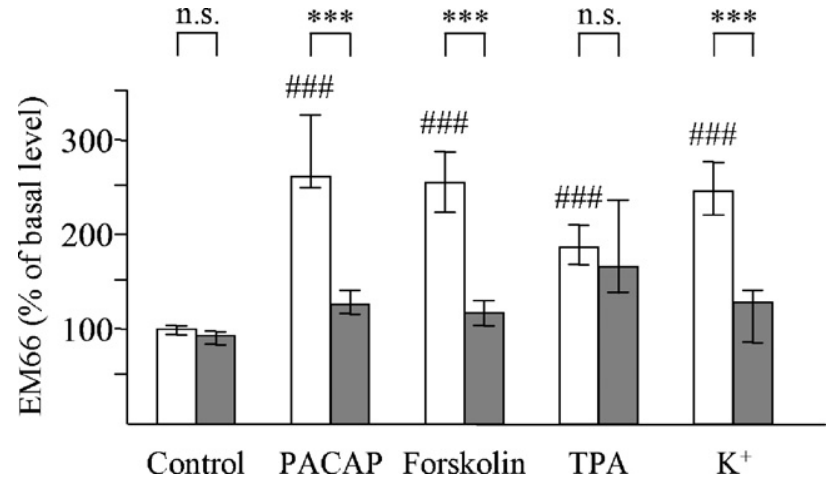

Fig. 10. Effect of protein synthesis inhibition on EM66 release stimulated by PACAP, forskolin, TPA or $\mathrm{K}^{+}$. Chromaffin cells were incubated for $24 \mathrm{~h}$ in control conditions or with $50 \mathrm{nM}$ PACAP, $25 \mu \mathrm{M}$ forskolin, $100 \mathrm{nM}$ TPA or $25 \mathrm{mM} \mathrm{K}^{+}$in the absence (open bars) or presence (gray bars) of $0.5 \mu \mathrm{g} / \mathrm{ml}$ cycloheximide. Values represent the median and 25th-75th percentile of EM66 concentration in the culture medium, expressed as percentages of basal level (corresponding controls). ${ }^{\# \#} p<0.001$ vs control, $* * * p<0.001$ cycloheximidetreated cells $v s$ cycloheximide untreated cells. n.s., not significant.

[7]. Moreover, EM66 is generated early during the ontogenesis of the fetal human adrenal gland [5], suggesting that its formation is necessary throughout life. The sequence of SgII contains nine pairs of basic amino acids which represent potential cleavage sites by the endopeptidases PC1 and PC2 [32]. It has been previously shown that, in the rat PC12 chromaffin cell line, SgII can be cleaved by PC1 and PC2 to generate several fragments including SN $[33,34]$. The fact that both PC1 and $\mathrm{PC} 2$ are expressed in the bovine adrenal gland strongly suggests that these prohormone convertases are involved in the processing of SgII to generate mature EM66. Interestingly, Western blot analysis revealed a differential pattern of EM66immunoreactive bands between adrenal medulla and adrenal cortex extracts. This result indicates the existence of different processing mechanisms of SgII in medullary $v s$ extramedullary adrenal chromaffin cells, which can be due to differential regulation of PCs activities probably related to the expression of PC inhibitors [35] or the accumulation of catecholamines which inhibit PCs [36].

It is well established that, in chromaffin cells of the adrenal medulla, PACAP acting through PAC1-R, exerts a stimulatory effect on catecholamine secretion that persists for several hours [11]. PACAP also stimulates the expression of genes encoding various neuropeptides such as galanin [37] and VIP [38], and the release of enkephalins and brain natriuretic peptides $[11,12]$. Concerning chromogranins, which are co-stored with catecholamines within secretory granules of chromaffin cells, Turquier et al. [20] previously showed that PACAP increases SgII gene transcription and SN release. In contrast, CgA mRNA levels were not affected by PACAP treatment, indicating that the neuropeptide exerts a gene-specific effect on members of the $\mathrm{Cg}$ family in bovine chromaffin cells. In addition to SN, PACAP also stimulated the secretion of EM66 from chromaffin cells which have the ability to release appreciable amounts of EM66 in the culture medium. Together with the immunohistochemical experiments indicating the occurrence of EM66-IR in cultured chromaffin cells and HPLC analysis showing the presence of a 
major EM66-immunoreactive peak co-eluting with the recombinant peptide in culture medium extracts, these data demonstrate that EM66 is produced by chromaffin cells and is released from these cells upon stimulation.

The $\mathrm{ED}_{50}(\approx 5 \mathrm{nM})$ of PACAP-stimulated EM66 secretion was similar to that observed for PACAP-induced SN secretion $\left(\mathrm{ED}_{50} \approx 3 \mathrm{nM},[20]\right)$, in agreement with the high-affinity binding of PACAP to the PAC1-R expressed in bovine chromaffin cells. Kinetic experiments indicated that PACAP-evoked EM66 secretion occurred after $6 \mathrm{~h}$ of treatment, reached a plateau phase at $48-72 \mathrm{~h}$ and lasted up to $96 \mathrm{~h}$. These data confirm those reported previously showing that PACAP exerts long-lasting effects on the secretory activity of chromaffin cells [11]. In contrast to SN release which occurred within 5 min [20], EM66 secretion could be detected only after $6 \mathrm{~h}$ of exposure to the neuropeptide. Since it has been shown that PACAP stimulated SgII gene expression after $1 \mathrm{~h}$, these observations suggest that, in bovine chromaffin cells, PACAP induces the release of preexisting pools of SN whereas the effect on EM66 secretion could be directly dependent on SgII biosynthesis and processing. In accordance, we found that PACAP, high potassium concentration and forskolin-induced EM66 secretion were almost completely blocked $(\approx 90 \%)$ by the protein synthesis inhibitor cycloheximide. Alternatively, since the basal level of EM66 is 5-fold higher than that of $\mathrm{SN}$, and since PACAP induces a lower maximal fold increase of EM66 (2.6-fold) compared to SN (5-fold), one would predict that PACAP causes modest EM66 variation that remains undetectable until $6 \mathrm{~h}$ of treatment.
The PAC1-R has been shown to activate several second messengers including cAMP, $\mathrm{IP}_{3}$ and $\mathrm{Ca}^{2+}$ in bovine chromaffin cells [39-41]. Using extra- and intracellular $\mathrm{Ca}^{2+}$ blockers, we found that the effect of PACAP on EM66 release is associated with activation of L-type $\mathrm{Ca}^{2+}$ channels and elevation of cytosolic $\mathrm{Ca}^{2+}$ concentrations. However, since nimodipine partially blocked the PACAP effect, other types of voltage-operated $\mathrm{Ca}^{2+}$ channels may be involved in EM66 secretion. Similar $\mathrm{Ca}^{2+}$ signaling routes were shown to be involved in PACAP-induced $\mathrm{SN}$ secretion [20]. However, the effects of $\mathrm{Ca}^{2+}$ inhibitors were much lower on SN than EM66 release, indicating a predominance of this second messenger pathway in EM66 secretion.

The general protein kinase inhibitor H7, almost completely blocked the PACAP-induced stimulation of EM66 secretion. In fact, we observed that PKA, PKC, p38 and ERK1/2 blockers were, with equivalent potency, very effective in reducing the PACAP effect. Moreover, concomitant administration of $\mathrm{H} 7$ and $\mathrm{Ca}^{2+}$ blockers totally suppressed PACAP-evoked EM66 release. Altogether these results indicate that multiple signaling pathways involving $\mathrm{Ca}^{2+}$, PKA, PKC and MAPK (Fig. 11) are collectively activated by PACAP to induce maximal stimulation of EM66 secretion. Further studies will be necessary to elucidate the crosstalks between these transduction pathways and the sequence of their activation by PACAP to trigger EM66 release. It has been shown in PC12 cells, that PACAP induces GTP-loading of Rap 1 and co-activation of PKA, PKC or Ras to efficiently stimulate ERK1/2 [42] and p38 through activation of a phospholipase $\mathrm{C}$, mobilization of intracellular $\mathrm{Ca}^{2+}$ stores and $\mathrm{Ca}^{2+}$ influx via voltage-dependent $\mathrm{Ca}^{2+}$ channels [43]. Because

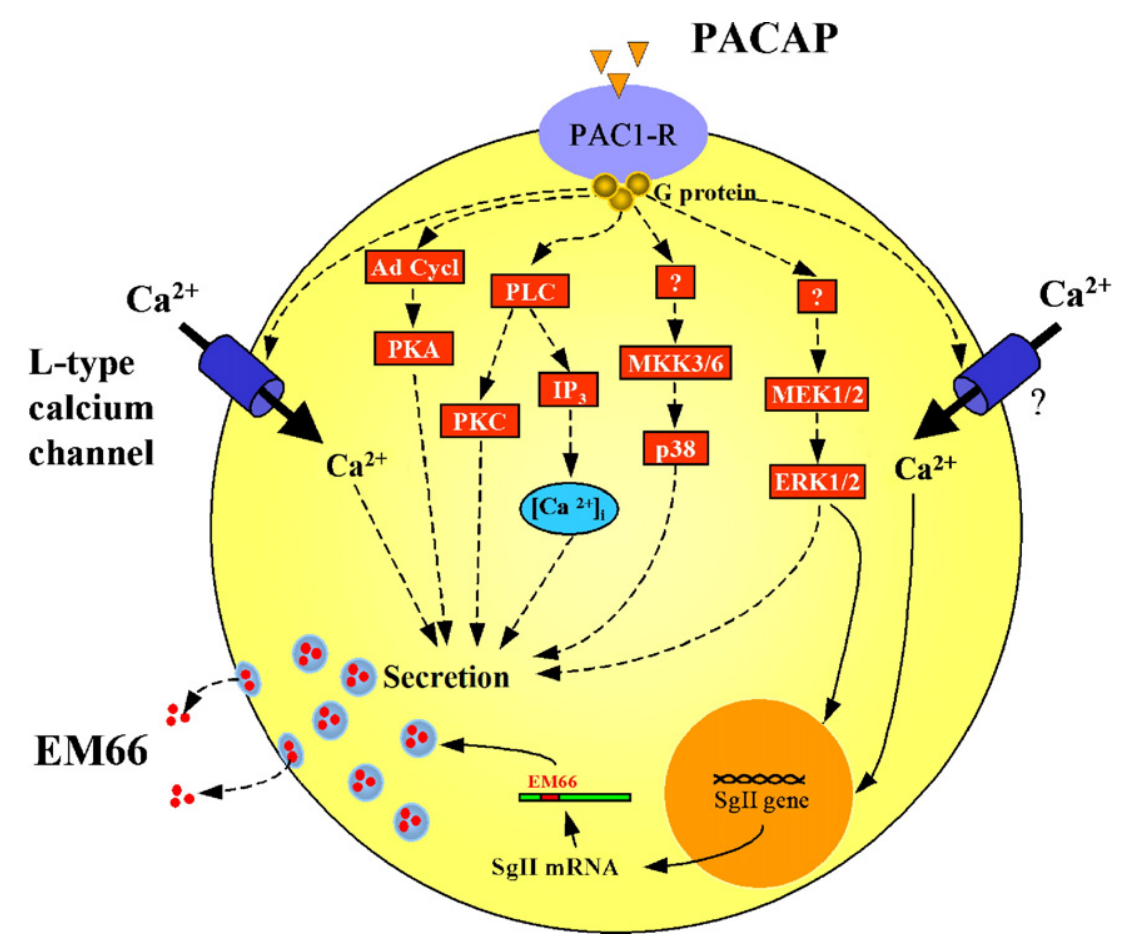

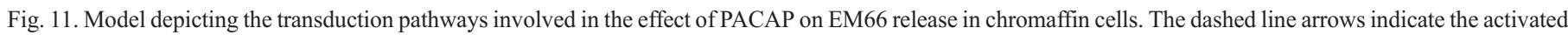

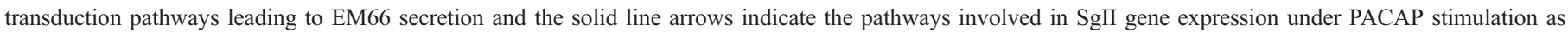

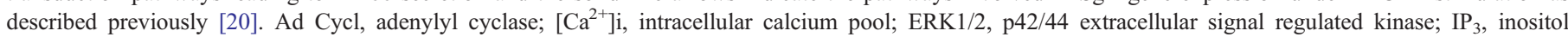

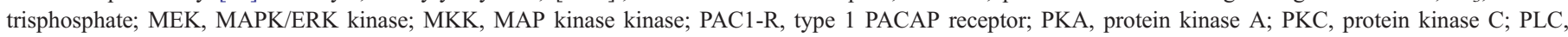
phospholipase C. 
PACAP stimulation of EM66 involved several of these transduction components, it could be interesting to determine whether a similar sequential activation of these mechanisms also occurs in primary chromaffin cells.

Taken together, as summarized in Fig. 11, our results show that, in bovine chromaffin cells, PACAP, probably through PAC1-R, activates multiple signaling pathways including intraand extracellular $\mathrm{Ca}^{2+}$ mobilization, PKA, PKC, p38 and ERK $1 / 2$ MAPK to induce EM66 secretion. Although the release of EM66 exhibited several similarities with that of SN, the former seems to rely primarily on pools of newly synthesized peptide whereas the latter probably involves a pre-existing pool of peptide. Moreover, p38 and ERK1/2 MAPK transduction routes are implicated to the same extent in EM66 release while mainly ERK1/2 is involved in SN secretion. Thus, the fine tuning of the release of SgII-derived peptides by a neurocrine factor suggests that SN and EM66 may act differently after release from neuroendocrine cells.

\section{Acknowledgments}

The authors wish to thank Mrs H. Lemonnier for technical assistance. This work was supported by the Institut National de la Santé et de la Recherche Médicale (Unité 413), the European Institute for Peptide Research (IFRMP 23), the Regional Platform for Cell Imaging and the Conseil Régional de HauteNormandie. J.G. is the recipient of a doctoral fellowship from the Conseil Régional de Haute-Normandie. H.V. is an Affiliate Professor at the INRS-Institut Armand Frappier (Montreal, Canada).

\section{References}

[1] Taupenot L, Harper KL, O'Connor DT. The chromogranin-secretogranin family. N Engl J Med 2003;348:1134-49.

[2] Vaudry H, Conlon JM. Identification of a peptide arising from the specific post-translation processing of secretogranin II. FEBS Lett 1991;284:31-3.

[3] Fischer-Colbrie R, Kirchmair R, Kahler CM, Wiedermann CJ, Saria A. Secretoneurin: a new player in angiogenesis and chemotaxis linking nerves, blood vessels and the immune system. Curr Protein Pept Sci 2005; 6: 373-85.

[4] Anouar Y, Jegou S, Alexandre D, Lihrmann I, Conlon JM, Vaudry H. Molecular cloning of frog secretogranin II reveals the occurrence of several highly conserved potential regulatory peptides. FEBS Lett 1996;394: 295-9.

[5] Anouar Y, Desmoucelles C, Yon L, Leprince J, Breault L, Gallo-Payet N, et al. Identification of a novel secretogranin II-derived peptide (SgII(187252)) in adult and fetal human adrenal glands using antibodies raised against the human recombinant peptide. J Clin Endocrinol Metab 1998;83: 2944-51.

[6] Montero-Hadjadje M, Pelletier G, Yon L, Li S, Guillemot J, Magoul R, et al. Biochemical characterization and immunocytochemical localization of EM66, a novel peptide derived from secretogranin II, in the rat pituitary and adrenal glands. J Histochem Cytochem 2003;51:1083-95.

[7] Boutahricht M, Guillemot J, Montero-Hadjadje M, Bellafqih S, El Ouezzani S, Alaoui A, et al. Biochemical characterisation and immunohistochemical localisation of the secretogranin II-derived peptide EM66 in the hypothalamus of the jerboa (Jaculus orientalis): modulation by food deprivation. J Neuroendocrinol 2005;17:372-8.

[8] Guillemot J, Anouar Y, Montero-Hadjadje M, Grouzmann E, Grumolato L, Roshmaninho-Salgado J, et al. Circulating EM66 is a highly sensitive marker for the diagnosis and follow-up of pheochromocytoma. Int $\mathrm{J}$ Cancer 2006;118:2003-12.

[9] Yon L, Guillemot J, Montero-Hadjadje M, Grumolato L, Leprince J, Lefebvre $\mathrm{H}$, et al. Identification of the secretogranin II-derived peptide EM66 in pheochromocytomas as a potential marker for discriminating benign versus malignant tumors. J Clin Endocrinol Metab 2003;88: 2579-85.

[10] Dun NJ, Tang H, Dun SL, Huang R, Dun EC, Wakade AR. Pituitary adenylate cyclase activating polypeptide-immunoreactive sensory neurons innervate rat adrenal medulla. Brain Res 1996;716:11-21.

[11] Babinski K, Bodart V, Roy M, De Lean A, Ong H. Pituitary adenylate cyclase-activating polypeptide (PACAP) evokes long-lasting secretion and de novo biosynthesis of bovine adrenal medullary neuropeptides. Neuropeptides 1996;30:572-82.

[12] Hahm SH, Hsu CM, Eiden LE. PACAP activates calcium influx-dependent and -independent pathways to couple met-enkephalin secretion and biosynthesis in chromaffin cells. J Mol Neurosci 1998;11:43-56.

[13] Hamelink C, Tjurmina O, Damadzic R, Young WS, Weihe E, Lee HW, et al. Pituitary adenylate cyclase-activating polypeptide is a sympathoadrenal neurotransmitter involved in catecholamine regulation and glucohomeostasis. Proc Natl Acad Sci U S A 2002;99:461-6.

[14] Lamouche S, Yamaguchi N. Role of PAC(1) receptor in adrenal catecholamine secretion induced by PACAP and VIP in vivo. Am J Physiol Regul Integr Comp Physiol 2001;280:510-8.

[15] Mazzocchi G, Malendowicz LK, Rebuffat P, Gottardo L, Nussdorfer GG. Expression and function of vasoactive intestinal peptide, pituitary adenylate cyclase-activating polypeptide, and their receptors in the human adrenal gland. J Clin Endocrinol Metab 2002;87:2575-80.

[16] Taupenot L, Mahata SK, Wu H, O'Connor DT. Peptidergic activation of transcription and secretion in chromaffin cells. Cis and trans signaling determinants of pituitary adenylyl cyclase-activating polypeptide (PACAP). J Clin Invest 1998;101:863-76.

[17] Tonshoff C, Hemmick L, Evinger MJ. Pituitary adenylate cyclase activating polypeptide (PACAP) regulates expression of catecholamine biosynthetic enzyme genes in bovine adrenal chromaffin cells. J Mol Neurosci 1997;9:127-40.

[18] Vaudry D, Gonzalez BJ, Basille M, Yon L, Fournier A, Vaudry H. Pituitary adenylate cyclase-activating polypeptide and its receptors: from structure to functions. Pharmacol Rev 2000;52:269-324.

[19] Bauer JW, Kirchmair R, Egger C, Fischer-Colbrie R. Histamine induces a gene-specific synthesis regulation of secretogranin II but not of chromogranin A and B in chromaffin cells in a calcium-dependent manner. J Biol Chem 1993;268:1586-9.

[20] Turquier V, Yon L, Grumolato L, Alexandre D, Fournier A, Vaudry H, et al. Pituitary adenylate cyclase-activating polypeptide stimulates secretoneurin release and secretogranin II gene transcription in bovine adrenochromaffin cells through multiple signaling pathways and increased binding of pre-existing activator protein-1-like transcription factors. Mol Pharmacol 2001;60:42-52.

[21] Wolkersdorfer M, Egger C, Laslop A, Fischer-Colbrie R. Nicotine and prostaglandin E induce secretogranin II levels in bovine chromaffin cells. Brain Res Mol Brain Res 1996;38:260-6.

[22] Chartrel N, Tonon MC, Vaudry H, Conlon JM. Primary structure of frog pituitary adenylate cyclase-activating polypeptide (PACAP) and effects of ovine PACAP on frog pituitary. Endocrinology 1991;129:3367-71.

[23] Benjannet S, Reudelhuber T, Mercure C, Rondeau N, Chretien M, Seidah NG. Proprotein conversion is determined by a multiplicity of factors including convertase processing, substrate specificity, and intracellular environment. Cell type-specific processing of human prorenin by the convertase PC1. J Biol Chem 1992;267:11417-23.

[24] Seidah NG, Marcinkiewicz M, Benjannet S, Gaspar L, Beaubien G, Mattei $\mathrm{MG}$, et al. Cloning and primary sequence of a mouse candidate prohormone convertase PC1 homologous to PC2, Furin, and Kex2: distinct chromosomal localization and messenger RNA distribution in brain and pituitary compared to PC2. Mol Endocrinol 1991;5:111-22.

[25] Anouar Y, MacArthur L, Cohen J, Iacangelo AL, Eiden LE. Identification of a TPA-responsive element mediating preferential transactivation of the galanin gene promoter in chromaffin cells. J Biol Chem 1994;269: 6823-31. 
[26] Ait-Ali D, Turquier V, Grumolato L, Yon L, Jourdain M, Alexandre D, et al. The proinflammatory cytokines tumor necrosis factor-alpha and interleukin-1 stimulate neuropeptide gene transcription and secretion in adrenochromaffin cells via activation of extracellularly regulated kinase 1 / 2 and p38 protein kinases, and activator protein-1 transcription factors. Mol Endocrinol 2004;18:1721-39.

[27] Bornstein SR, Ehrhart-Bornstein M, Usadel H, Bockmann M, Scherbaum WA. Morphological evidence for a close interaction of chromaffin cells with cortical cells within the adrenal gland. Cell Tissue Res 1991;265:1-9.

[28] Gallo-Payet N, Pothier P, Isler H. On the presence of chromaffin cells in the adrenal cortex: their possible role in adrenocortical function. Biochem Cell Biol 1987;65:588-92.

[29] Perraudin V, Delarue C, Lefebvre H, Contesse V, Kuhn JM, Vaudry H. Vasopressin stimulates cortisol secretion from human adrenocortical tissue through activation of V1 receptors. J Clin Endocrinol Metab 1993;76: 1522-8.

[30] Bornstein SR, Tian H, Haidan A, Bottner A, Hiroi N, Eisenhofer G, et al. Deletion of tyrosine hydroxylase gene reveals functional interdependence of adrenocortical and chromaffin cell system in vivo. Proc Natl Acad Sci U S A 2000;97:14742-7.

[31] Delarue C, Contesse V, Lenglet S, Sicard F, Perraudin V, Lefebvre H, et al. Role of neurotransmitters and neuropeptides in the regulation of the adrenal cortex. Rev Endocr Metab Disord 2001;2:253-67.

[32] Seidah NG, Gaspar L, Mion P, Marcinkiewicz M, Mbikay M, Chretien M. cDNA sequence of two distinct pituitary proteins homologous to Kex2 and furin gene products: tissue-specific mRNAs encoding candidates for prohormone processing proteinases. DNA Cell Biol 1990;9:415-24.

[33] Dittie AS, Tooze SA. Characterization of the endopeptidase PC2 activity towards secretogranin II in stably transfected PC12 cells. Biochem J 1995;310:777-87.

[34] Laslop A, Weiss C, Savaria D, Eiter C, Tooze SA, Seidah NG, et al. Proteolytic processing of chromogranin B and secretogranin II by prohormone convertases. J Neurochem 1998;70:374-83.

[35] Hwang SR, Steineckert B, Yasothornsrikul S, Sei CA, Toneff T, Rattan J, Hook VY. Molecular cloning of endopin 1, a novel serpin localized to neurosecretory vesicles of chromaffin cells. Inhibition of basic residuecleaving proteases by endopin 1. J Biol Chem 1999;274:34164-73.

[36] Wolkersdorfer M, Laslop A, Lazure C, Fischer-Colbrie R, Winkler H. Processing of chromogranins in chromaffin cell culture: effects of reserpine and alpha-methyl-p-tyrosine. Biochem J 1996;316:953-8.

[37] Anouar Y, Lee HW, Eiden LE. Both inducible and constitutive activator protein-1-like transcription factors are used for transcriptional activation of the galanin gene by different first and second messenger pathways. Mol Pharmacol 1999;56:162-9.

[38] Lee HW, Hahm SH, Hsu CM, Eiden LE. Pituitary adenylate cyclaseactivating polypeptide regulation of vasoactive intestinal polypeptide transcription requires $\mathrm{Ca}^{2+}$ influx and activation of the serine/threonine phosphatase calcineurin. J Neurochem 1999;73:1769-72.

[39] Spengler D, Waeber C, Pantaloni C, Holsboer F, Bockaert J, Seeburg PH, et al. Differential signal transduction by five splice variants of the PACAP receptor. Nature 1993;365:170-5.

[40] Tanaka K, Shibuya I, Nagamoto T, Yamashita H, Kanno T. Pituitary adenylate cyclase-activating polypeptide causes rapid $\mathrm{Ca}^{2+}$ release from intracellular stores and long lasting $\mathrm{Ca}^{2+}$ influx mediated by $\mathrm{Na}+$ influxdependent membrane depolarization in bovine adrenal chromaffin cells. Endocrinology 1996;137:956-66.

[41] Tanaka K, Shibuya I, Uezono Y, Ueta Y, Toyohira Y, Yanagihara N, et al. Pituitary adenylate cyclase-activating polypeptide causes $\mathrm{Ca}^{2+}$ release from ryanodine/caffeine stores through a novel pathway independent of both inositol trisphosphates and cyclic AMP in bovine adrenal medullary cells. J Neurochem 1998;70:1652-61.

[42] Bouschet T, Perez V, Fernandez C, Bockaert J, Eychene A, Journot L. Stimulation of the ERK pathway by GTP-loaded Rap1 requires the concomitant activation of Ras, protein kinase $\mathrm{C}$, and protein kinase $\mathrm{A}$ in neuronal cells. J Biol Chem 2003;278:4778-85.

[43] Sakai Y, Hashimoto H, Shintani N, Ichibori A, Tomimoto S, Tanaka K, et al. Involvement of intracellular $\mathrm{Ca}^{2+}$ elevation but not cyclic AMP in PACAP-induced p38 MAP kinase activation in PC12 cells. Regul Pept 2002;109:149-53. 